\title{
Complex facial reconstruction using local anesthesia - case presentation
}

\author{
Reconstrucţie facială complexă utilizând anestezia locală - prezentare de caz \\ Cătălin BEJINARIU1 ${ }^{1}$, Carmen GIUGLEA ${ }^{2}$, Silviu MARINESCU ${ }^{1}$ \\ ${ }^{1}$ Secția de Chirurgie Plastică şi Microchirurgie Reconstructivă, \\ Spitalul Clinic de Urgență „Bagdasar-Arseni“, Bucureşti, România \\ ${ }^{2}$ Secția de Chirurgie Plastică, Estetică şi Microchirurgie Reconstructivă, \\ Spitalul Clinic de Urgență „Sfântul Ioan“, Bucureşti, România
}

\section{ABSTRACT}

Basal cell carcinoma occupies a leading place among cutaneous neoplasms, exposure to solar radiation being the main incriminating factor in the occurrence of this type of cancer. The present paper presents a complex case of facial reconstruction using local anesthesia, performed in order to cover the defect remaining after the excision of a basal cell carcinoma located at the level of the infraorbital region. The tumor excision, the dissection of the cheek flap and its rotation to cover the defect were performed after the infiltration of the anesthetic solution at the level of the right hemiface, so that during the entire operation the patient was aware, constantly communicating with the surgical team.

Without a doubt the early identification of this condition and the rapid establishment of the surgical treatment can be associated with a favorable prognosis. The photographs taken 12 months after the surgical intervention show that this type of intervention is associated with favorable aesthetic results under the conditions of eliminating the risks associated with general anesthesia.
\end{abstract}

Keywords: facial reconstruction, local anesthesia, basal cell carcinoma

\section{REZUMAT}

Carcinomul bazocelular ocupă un loc fruntaş în rândul neoplaziilor cutanate, expunerea la radiațiile solare fiind principalul factor incriminant în apariția acestui tip de cancer.

Lucrarea de față prezintă un caz complex de reconstrucție facială cu anestezie locală, efectuată pentru acoperirea defectului restant în urma exciziei unui carcinom bazocelular localizat la nivelul regiunii infraorbitale, intervenția chirurgicală efectuându-se cu anestezie locală. Realizarea exciziei tumorale, a disecției lamboului de obraz şi rotarea acestuia pentru acoperirea defectului au fost efectuate după infiltrarea soluției anestezice la nivelul hemifeței drepte, astfel încât, pe toată durata efectuării operației, pacientul a fost conştient, comunicând în mod constant cu echipa operatorie.

Fără doar şi poate, identificarea precoce a acestei afecțiuni şi instituirea rapidă a tratamentului chirurgical se asociază cu un prognostic favorabil. Fotografiile efectuate la 12 luni de la realizarea intervenției chirurgicale arată că acest tip de intervenție se asociază cu rezultate estetice favorabile în condițiile eliminării riscurilor asociate anesteziei generale.

Cuvinte cheie: reconstrucție facială, anestezie locală, carcinom bazocelular 


\section{INTRODUCERE}

Formele de carcinom bazocelular identificate în stadii incipiente se asociază cu o rată crescută de vindecare în cazul efectuării tratamentului chirurgical, însă nu sunt rare cazurile în care pacienții se prezintă la consult în forme avansate ale bolii, situație în care excizia radicală trebuie asociată cu reconstrucții complexe (1-3) pentru acoperirea defectului de părți moi rămas în urma îndepărtării formațiunii tumorale. Frecvent, acest tip de intervenții chirurgicale complicate solicită efectuarea anesteziei generale, expunând astfel pacientul la riscuri suplimentare asociate procesului anestezic. În ultimii ani, atenția specialiștilor din domeniul chirurgical s-a îndreaptă către reducerea acestor riscuri prin realizarea tratamentului chirurgical utilizând anestezia locală și regională (4-7).

Elaborarea unor soluții anestezice care vizează, pe de-o parte, creșterea gradului de confort intraoperator, iar, pe de altă parte, facilitarea realizării disecției chirurgicale prin controlul minuțios al sângerării (8-11) a constituit un pas extrem de important în introducerea noului concept de tratament, bazat pe creșterea profilului de siguranță al intervențiilor chirurgicale.

\section{PREZENTARE DE CAZ}

Articolul prezintă cazul unui pacient caucazian, în vârstă de 69 de ani, care a venit la Spitalul Clinic de Urgență „Bagdasar-Arseni“ pentru consult de specialitate în vederea efectuării tratamentului chirurgical pentru o formațiune tumorală ulcerată localizată la nivelul regiunii infraorbitale drepte.
Pacientul a relatat că formațiunea tumorală apăruse în urmă cu aproximativ 5 ani, crescând progresiv în dimensiuni până la momentul consultului. Examinarea locală a evidențiat o formațiune tumorală ulcerată cu profunzimea de aproximativ 8 $\mathrm{mm}$, diametrul de $3 \mathrm{~cm}$, consistență dură și aderență crescută la planul profund (Figura 1). Anamneza nu a relevat existența antecedentelor personale patologice semnificative.

În urma efectuării examinării clinice și a investigațiilor paraclinice uzuale, s-a propus efectuarea exciziei formațiunii tumorale cu realizarea examenului histopatologic extemporaneu, urmată de reconstrucția regiunii faciale prin utilizarea unui lambou de obraz rotat (Figura 2). În ceea ce privește anestezia necesară efectuării reconstrucției, s-a optat pentru realizarea anesteziei locale prin infiltrarea unei soluții anestezice conținând xilină, bicarbonat și adrenalină în raport de 10:1:0,1, cantitatea necesară de soluție fiind de $25 \mathrm{ml}$.

Intervenția chirurgicală reconstructivă a durat 120 de minute, pe toata durata operației pacientul fiind echilibrat și fără acuze algice. În urma examinării histopatologice, a fost stabilit diagnosticul de carcinom bazocelular, pacientul fiind externat la 2 zile postoperator cu evoluție locală favorabilă.

Evaluările postoperatorii efectuate la 14 zile și, ulterior, la 3, 6, 9 și 12 luni au identificat o evoluție locală favorabilă cu obținerea unui rezultat estetic foarte bun (Figura 3).

\section{DISCUȚII}

Literatura de specialitate arată că incidența carcinomului bazocelular este în creștere în ulti-

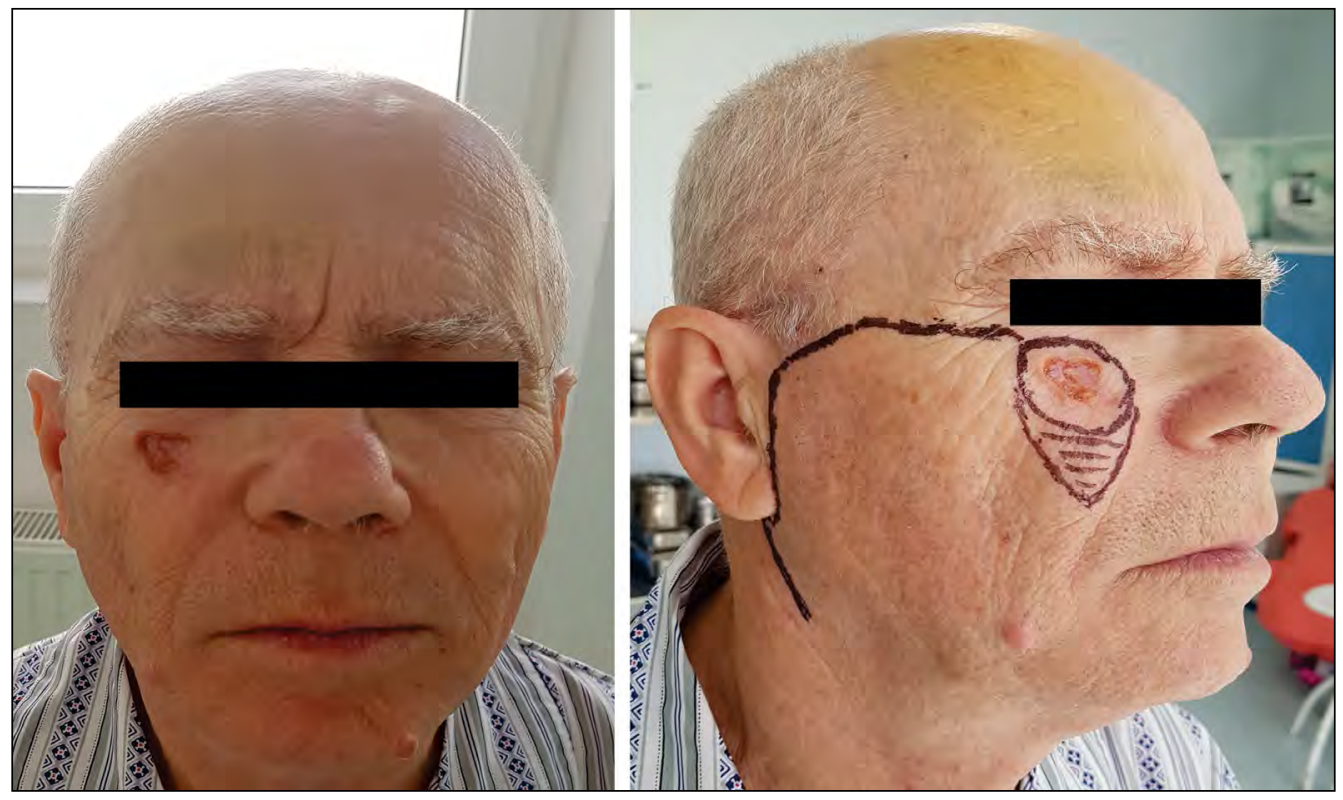

FIGURA 1. Aspect preoperator 

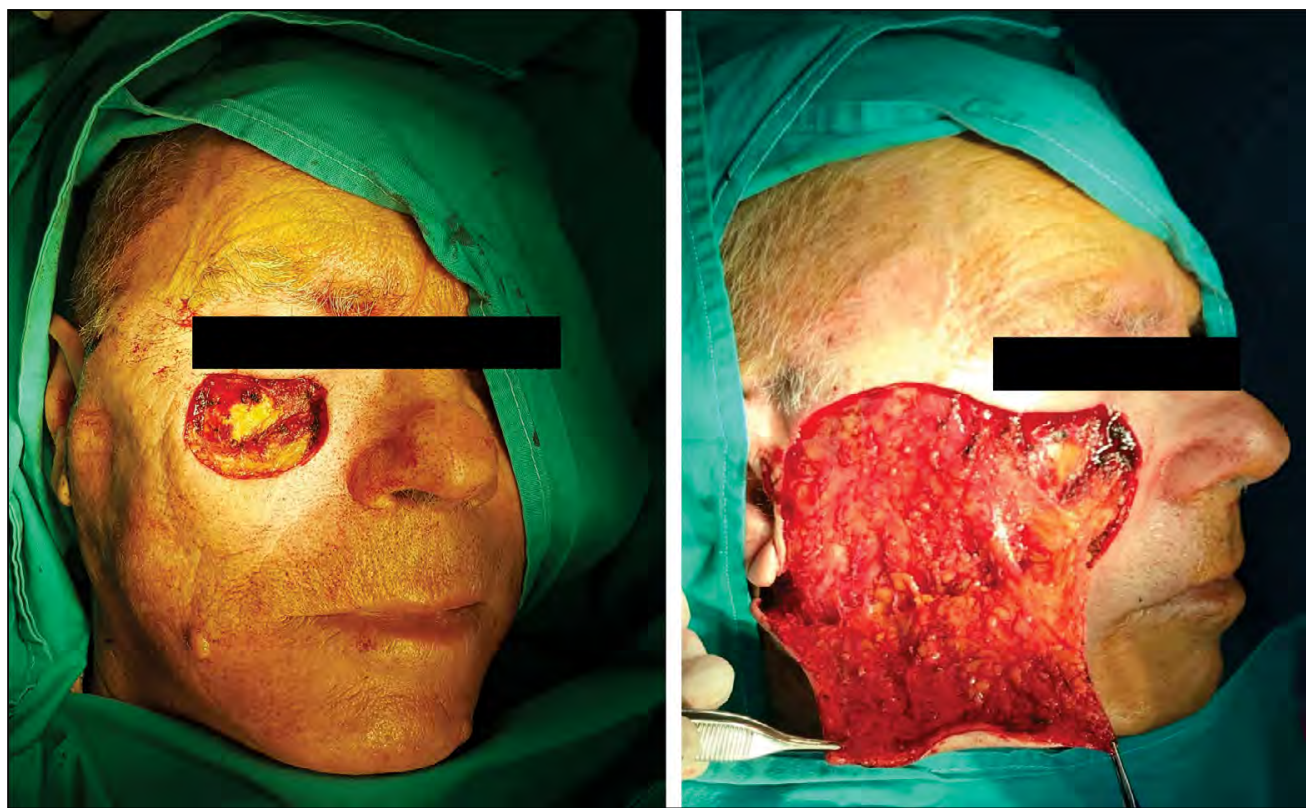

FIGURA 2. Aspect intraoperator
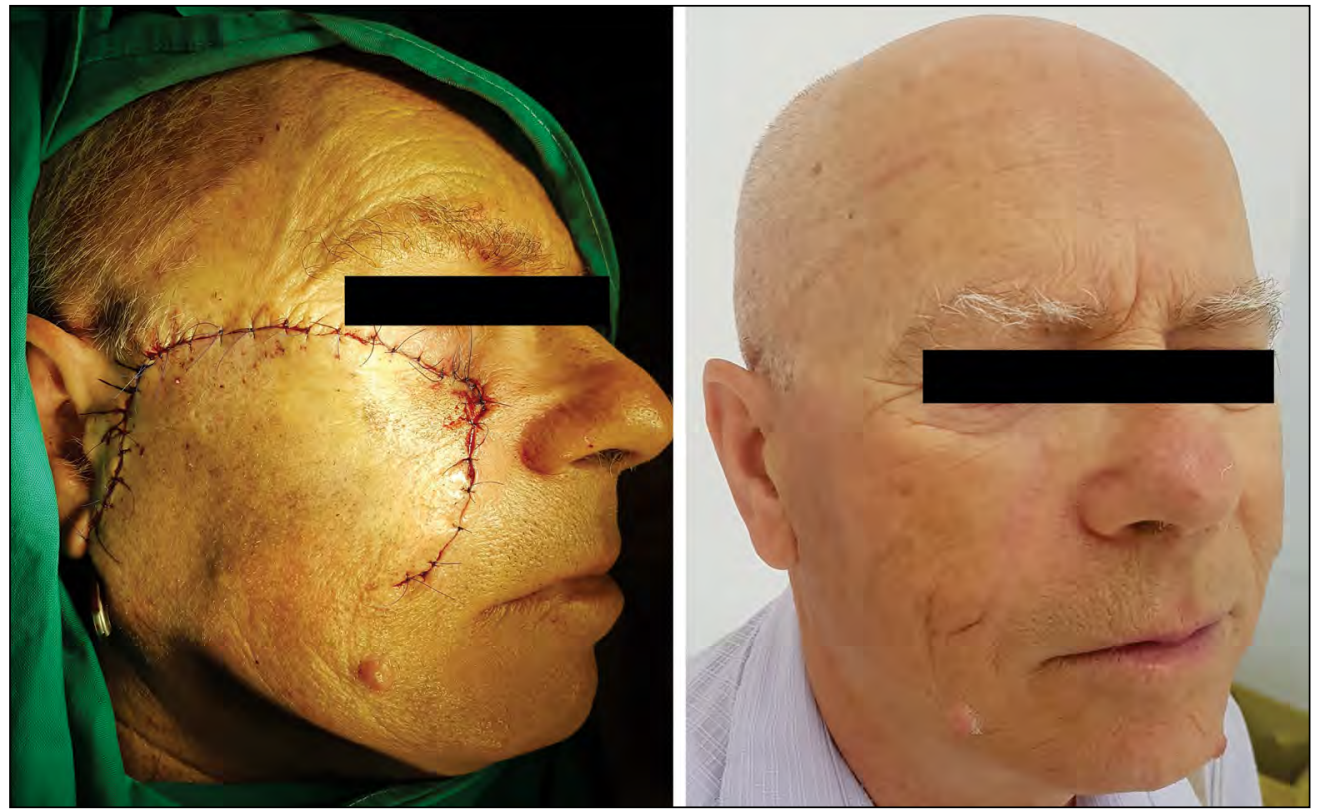

FIGURA 3. Aspect postoperator

mul deceniu, factorii incriminați fiind expunerea prelungită la soare, creșterea duratei de viață, precum și îmbunătățirea sistemelor de diagnosticare (12-14). Tratamentul chirurgical are un prognostic favorabil, riscul de recidivă locală fiind foarte redus în aceste situații. Cu toate acestea, nu trebuie neglijat faptul că lipsa educației sanitare în țările aflate în curs de dezvoltare face posibilă identificarea cazurilor grave, care impun realizarea de excizii largi ce implică efectuarea de intervenții chirurgicale reconstructive complexe pentru acoperirea defectelor de părți moi restante în urma îndepărtării formațiunii tumorale (15-18).
În lumina celor prezentate, se evidențiază necesitatea de formare a unor echipe de specialiști experimentați în efectuarea tratamentului chirurgical excizional și reconstructiv necesar soluționării acestor cazuri complexe. Realizarea acestor intervenții chirurgicale complicate cu anestezie locală creează premisele creșterii semnificative a numărului de pacienți care ar putea beneficia de tratament chirurgical de specialitate.

Studiul de caz prezentat arată că prin utilizarea anesteziei locale se pot realiza atât cura oncologică, cât și reconstrucția necesară acoperirii defectelor postexcizionale, fără a expune pacientul la ris- 
curile suplimentare asociate anesteziei generale. Utilizarea bicarbonatului de sodiu în rețeta soluției anestezice se asociază cu o creștere semnificativă a confortului intraoperator, cu precădere în etapele inițiale ale efectuării anesteziei. Efectul vasoconstrictor al adrenalinei oferă beneficii semnificative atât în momentul realizării exciziei formațiunii tumorale (19-21), prin vizualizarea amănunțită a structurilor anatomice, cât și în momentul disecției lamboului, menținerea planului subcutanat fiind mult ușurată de utilizarea acestei substanțe.

Un element care poate contribui la identificarea planului de disecție și la reducerea semnificativă a duratei intervenției este efectuarea disecției hidrice prin diluarea soluției anestezice cu ser fiziologic și injectarea acesteia în cadrul delimitat de desenul preoperator. Menținerea unui raport de 1:1 cu soluția anestezică are beneficiul de a păstra capacitatea de analgezie și vasoconstricție în condițiile facilitării realizării disecției lamboului.

Pentru ușurarea rotării lamboului de obraz, în vederea acoperirii defectului, incizia trebuie pre- lungită la nivel retroauricular și, în cazuri selecționate, la nivelul regiunii cervicale laterale. Stabilitatea reconstrucției este asigurată prin utilizarea firelor resorbabile plasate în planul profund la nivelul regiunii zigomatice, reducând totodată riscul formării de spații virtuale care ar putea predispune la formarea de hematoame și seroame postoperatorii. Această manevră are proprietatea de a reduce și tensiunea de la nivelul tranșelor de sutură, contribuind astfel, în mod semnificativ, la îmbunătățirea aspectului estetic al cicatricilor postoperatorii.

\section{CONCLUZII}

În lumina celor prezentate, tratamentul chirurgical al carcinomului bazocelular localizat la nivelul feței poate fi realizat cu anestezie locală, chiar și în cazurile în care dimensiunile și particularitățile locale ale formațiunii tumorale impun efectuarea unor excizii de mari dimensiuni care solicită efectuarea de intervenții chirurgicale reconstructive complexe.

Conflict of interest: none declared Financial support: none declared

\section{BIBLIOGRAFIE}

1. Cengizhan E, Erdem G, Emre H, Combined Scalp Flap and Cheek Flap in Large Cranial Defect. Journal of Craniofacial Surgery. 2016; 27(6):1613-1614

2. Ishii N, Takayama M, Sakai S et al. Does the Optimal Layer of the Skin Include the Orbicularis Oculi Muscle When Elevating Cheek Rotation Flap? J Cutan Aesthet Surg. 2019; 12(2): 112-117.

3. Williams HC, Bath-Hextall F, Ozolins M et al. Surgery Versus 5\% Imiquimod for Nodular and Superficial Basal Cell Carcinoma: 5-Year Results of the SINS Randomized Controlled Trial. Journal of Investigative Dermatology, 2017; 137(3): 614-619.

4. Kouba DJ, LoPiccolo MC, Alam M, Guidelines for the use of local anesthesia in office-based dermatologic surgery. Journal of the American Academy of Dermatology. 2016;74(6):1201-1219.

5. Ghita MA, Caruntu C, Rosca AE et al. Reflectance confocal microscopy and dermoscopy for in vivo, non-invasive skin imaging of superficial basal cell carcinoma. Oncology Letters. 2016; 11:3019-3024.

6. Wetzel M, Strickley J, Haeberle MT et al. Depth of Invasion of Aggressive and Nonaggressive Basal Cell Carcinoma. J Clin Aesthet Dermatol. 2019; 12(3):12-14.

7. Marinescu SA, Bejinariu CG, Giuglea C, Research Related to Breast Implantassociated Anaplastic Large Cell Lymphoma and its Influence on the Decision-Making Process Related to
Reconstructive Techniques Analysis of a series of cases and literature review. Mat Plast, 2019; 56(1):229-234.

8. Hufschmidt K, Bozec A, Camuzard O,Versatility of cervicofacial flaps: Cervical-medial cheek flap for reconstruction in cutaneous substance loss of the inner cheek. Head\&Neck. 2018; 40(12):2574-2582.

9. Bejinariu C, Marinescu S, Giuglea C, Studiu asupra reconstructiei de san dupa mastectomie la pacientele diabetic Romanian Medical Journal. 2019; 66(1):50-54.

10. Wetzel M, Strickley J, Haeberle MT et al. Depth of Invasion of Aggressive and Nonaggressive Basal Cell Carcinoma. J Clin Aesthet Dermatol. 2019; 12(3):12-14.

11. Bejinariu C, Apostolescu I, Marinescu S, Tratamentul cicatricilor postcombustionale de la nivelul sânului. Romanian Journal of Medical Practice. 2019; 14(1):62-65.

12. Ridky TW, Cotsarelis G, Vismodegib Resistance in Basal Cell Carcinoma: Not a Smooth Fit. Cancer Cell. 2015;27(3):315316.

13. Bejinariu CG, Marinescu SA, Enescu DM, The Romanian National Breast Reconstruction Program - Results and Conclusions after 5 Years. Modern Medicine. 2019;26(1):23-30.

14. Atwood SX, Sarin KY, Whitson RJ et al. Smoothened Variants Explain the Majority of Drug Resistance in Basal Cell Carcinoma. Cancer Cell. 2015; 27(3):342-353.
15. Marinescu SA, Bejinariu CG, Badeana A, Study on Reconstruction Techniques of the Nipple-Areola Complex. REV. CHIM. (Bucharest). 2019; 70(4):1234-1238.

16. Sharpe HJ, Pau G, Dijkgraaf GJ et al. Genomic Analysis of Smoothened Inhibitor Resistance in Basal Cell Carcinoma. Cancer Cell. 2015; 27 (3): 327-341.

17. Marinescu SA, Bejinariu CG, Sapte E et al. Complications related to breast reconstruction after mastectomy using multiple surgical techniques - a national and international comparative analysis. Rom J Morphol Embryol. 2019; 60(1):8793.

18. Verkouteren JAC, Ramdas KHR, Wakkee $M$, Epidemiology of basal cell carcinoma: scholarly review, British Journal of Dermatology. 2017; 177(2): 359-372.

19. Marzuka AG, Book SE, Basal Cell Carcinoma: Pathogenesis, Epidemiology, Clinical Features, Diagnosis, Histopathology, and Management. Yale $J$ Biol Med. 2015; 88(2):167-179.

20. Marinescu SA, Bejinariu CG, Boiangiu AM et al. Study on the concentrate of proteolytic enzymes enriched in bromelain and its effects on intermediate and extensive burns. Farmacia. 2019; 67(3):522-530.

21. Liu X, Liu Y, Chen K et al. Reconstruction of skin defects in the medial cheek using lateral cheek rotation flap combined with Z-plasties. J Plast Reconstr Aesthet Surg. 2015; 68(12):183-188. 